TI 2017-037/VIII

Tinbergen Institute Discussion Paper

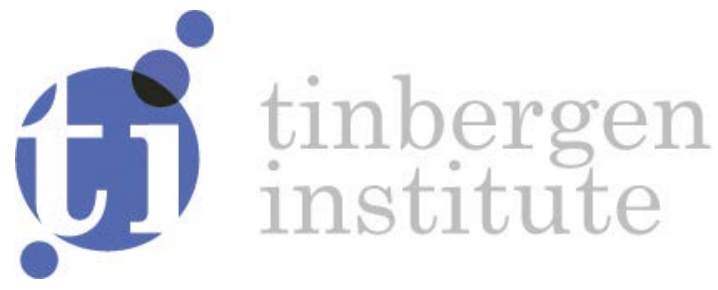

\title{
The impact of parking policy on house prices
}

J esper de Groote ${ }^{1}$

J os van Ommeren ${ }^{1,2}$

Hans R.A. Koster ${ }^{1,2}$

${ }^{1}$ Department of Spatial Economics, Vrije Universiteit Amsterdam

${ }^{2}$ Tinbergen Institute 
Tinbergen Institute is the graduate school and research institute in economics of Erasmus University Rotterdam, the University of Amsterdam and VU University Amsterdam.

Contact: discussionpapers@tinbergen.nl

More TI discussion papers can be downloaded at http://www.tinbergen.nl

Tinbergen Institute has two locations:

Tinbergen Institute Amsterdam

Gustav Mahlerplein 117

1082 MS Amsterdam

The Netherlands

Tel.: $+31(0) 205984580$

Tinbergen Institute Rotterdam

Burg. Oudlaan 50

3062 PA Rotterdam

The Netherlands

Tel.: +31(0)10408 8900 


\title{
The impact of parking policy on house prices
}

\author{
By JESPER DE GROOTE, ${ }^{a}$ JOS VAN OMMEREN ${ }^{b}$ and HANS R.A. KOSTER $^{c}$
}

This version: 10 April 2017

\begin{abstract}
Paid parking is the recommended policy tool by economists to deal with excess demand for street parking. However, we know very little about the effects of this policy on residents. This is particularly important in the context that residents have political power and usually vote against paid parking when it is detrimental to residents. Hence, in our analysis, we take into account that residents receive residential parking permits which provides political support for paid parking. We estimate the combined effect of a paid-parking parking policy - i.e. the introduction of paid parking and residential parking permits on residents - by examining its effect on house prices. We focus on Amsterdam and Utrecht using data over a period of 30 years. We do not find any effect of this paid-parking policy on house prices. This finding is consistent with the idea that residents only vote in favor of a local policy when it has no negative impact on their house prices.

JEL-code- R20, R40

Keywords - parking, parking policy, hedonic price analysis.
\end{abstract}

\section{Introduction}

City centers are prone to excess demand for parking since the invention of the car. This led to the introduction of paid parking as early as 1935 in Oklahoma in the US. In European city centers, parking tends to be an even bigger issue, because the urban structure usually has been laid out before the introduction of cars, so there is limited off-street parking whereas the ratio of on-street parking places to households is low in densely populated areas. Excess demand for parking leads to cruising because residents and visitors need to search for an available parking space (Van Ommeren et al., 2012).

Policymakers have reacted with different kinds of policies to the lack of parking spaces (Topp, 1991; Kodransky and Hermann, 2011). The main policies include the introduction of minimum parking requirements, residential parking areas, residential parking permits as well as the introduction of paid parking. Frequently, a combination of policies is used. For

a Corresponding author. Department of Spatial Economics, Vrije Universiteit Amsterdam, De Boelelaan 11051081 HV Amsterdam, e-mail: j.de.groote@vu.nl.

${ }^{b}$ Department of Spatial Economics, Vrije Universiteit Amsterdam, De Boelelaan 11051081 HV Amsterdam, e-mail: jos.van.ommeren@vu.nl. The author is also affiliated with the Tinbergen Institute, Gustav Mahlerplein 117, 1082 MS Amsterdam.

c Department of Spatial Economics, Vrije Universiteit Amsterdam, De Boelelaan 11051081 HV Amsterdam, e-mail: h.koster@vu.nl. The author is also affiliated with the Tinbergen Institute, Gustav Mahlerplein 117, 1082 MS Amsterdam. 
example, in the main cities of the Netherlands, paid parking is almost always combined with the use of residential parking permits. In almost all European countries - the main exception is Greece - we have seen a strong rise in the use of paid parking over the last 30 years.

The strong rise in paid parking is firmly supported by economic theory which indicates that paid parking is the preferred tool to regulate the on-street parking market (Arnott et al., 1991; Arnott and Rowse, 1999; Anderson and De Palma, 2004; Arnott and Inci, 2006). Sufficiently high parking prices reduce demand for on-street parking, which reduces cruising for parking and associated traffic congestion costs. In contrast to quantitative parking policies (such as minimum parking requirements), the use of paid parking is an attractive source of government revenue (Arnott and Rowse, 2009; Arnott, 2006).

Demand for parking by residents is strongly determined by car ownership. Ownership has increased strongly in the western world during the second half of the $20^{\text {th }}$ century (Dargay and Gately, 1999; Whelan, 2007). In Amsterdam and Utrecht, on which we focus in the analysis, car ownership increased particularly in the 1970s and 1980s. To deal with increasing demand, paid parking was introduced in most Dutch cities in the 1980s. However, paid parking was still restricted to city centers until the early 1990s. Things started to change when the Mulder Act was ratified in 1989 and municipalities were allowed to extract revenues from traffic violations, including parking. This led to a stricter parking policy with higher parking tariffs and strict enforcement. For example, in Amsterdam, in 1992, parking prices were strongly increased to limit demand in its city center. As car parking was discouraged through higher prices in the center, drivers parked their cars in surrounding areas, which led to the introduction of paid parking in these areas as well. A similar development of paid parking occurred in Utrecht, which witnessed a large increase of its paid-parking area in the mid-1990s.

Local residents played an important role in the decision whether paid parking is introduced. In Utrecht, until recently, residential parking was locally introduced after a (non-binding) referendum (Verkeersnet, 2013), whereas in Amsterdam, it is the local council which decides about the introduction of paid parking, after which the city government is allowed to set the price of street parking. Hence, residents could vote for parties that were for or against paid parking in their neighborhoods, dependent on their preferences.

In line with the idea that residents have political power about foreign policy, parking prices are usually not the same for residents and visitors. For example, while visitor parking tariffs can be as high as $€ 5$ per hour in the center of Amsterdam, residents pay roughly 2.5 percent of this price, as they can apply for residential parking permits. The price of such a permit is usually only enough to recover administration costs of the parking permit, about 100 euro and maximally 400 euro per year. In the Netherlands, in contrast to for example 
the UK and Italy, parking permits give residents the right to park in designated areas, but parking spaces in this area are also available to non-residents (Van Ommeren et al., 2011).

Despite the importance of paid parking, we know very little of the effect of these parking pricing policies on residents. Information on this effect is relevant, because residents have a strong influence on local parking policy either as voters or informally through lobbying. This suggests that it may not be possible for local governments to introduce welfare-improving parking policies that are detrimental for residents. This is also true for transport policies such as the introduction of road pricing (Marcucci et al., 2005; De Borger and Proost, 2012; Russo, 2013; Button, 2006). Hence, the timing of the introduction of paid parking is not random.

It seems plausible to assume that paid parking is introduced in areas with excess parking demand (by residents and visitors combined), so where cruising for parking is observed by the municipality. With rising car ownership levels in the absence of paid parking, the extent of cruising by residents will slowly increase over time, so the benefits of paid parking to local residents will increase over time. The introduction of paid parking combined with the introduction of residential parking permits reduces parking occupancy rates, because the demand for parking by non-residents will decrease. Hence, residents benefit because cruising time for parking is reduced (Shoup, 2004). These time savings depend on the severity of cruising before the paid-parking introduction. Hence, if they exceed the price of the residential parking permit, then local residents will favor the introduction of paid parking. Moreover, visitors related to residents (e.g. friends, family) should pay the high visitor parking price, which residents will usually dislike.

If there is a substantial benefit from the introduction of paid parking on residents, then the introduction will usually be reflected in higher housing prices. Arguably, this benefit may depend on whether residents own private residential off-street parking. It is plausible that this benefit will be smaller for residents that own private parking spaces, because they do not benefit directly from reductions in cruising time, which suggests that the prices of houses with private parking space may decrease compared to those without private parking space when paid parking is introduced. In the cities analyzed by us, private ownership of parking is rather scarce (about 6 percent of all houses). This makes it plausible that the majority of residents favor the introduction of paid parking, even when the minority of residents with privately-owned parking is not in favor.

In the current article, we estimate the combined effect of the introduction of paid parking and the provision of residential permits on location choices of residents through its effect on residential housing prices. We use data for Amsterdam and Utrecht, which are the capital and fourth largest city in the Netherlands. These cities together form the most important economic region of the Netherlands. We examine the combined effect of the introduction of paid parking and residential parking permits on housing prices by using a hedonic house price analysis over the last 30 years. We have annual information about the paid-parking 
area, which strongly expands over time, as well as housing price data, allowing us to estimate the effect of this parking policy on house prices. Our results show that there is no effect of this policy on housing prices, which suggests that the timing of the policy is optimal from the residents' point of view in line with the political economy argument. ${ }^{1}$ We note that standard errors are quite small, so that the lack of the statistically significant price effects is not related to a lack of precision.

The structure of this paper is as follows: Section II explains the econometric framework and Section III describes the data. Section IV gives the results, while Section V shows the sensitivity analysis. Section VI concludes.

\section{Econometric framework}

We aim to estimate the effect of parking policy on house prices in Amsterdam and Utrecht. Houses are considered to be bundles of attributes, such as floor space, maintenance and location, and therefore the value of paid parking can be determined by a hedonic regression (Brown and Rosen, 1982; Palmquist, 1984; and Rosen, 1974). In Amsterdam and Utrecht, the large majority of houses are apartments. We focus on the price effects for apartments because of their high floor-to-area ratio, so apartments are most prone to parking scarcity. This also eliminates variation in unobserved house and street characteristics between the city center and other areas, which should yield more accurate results.

One statistical issue is that paid parking is more likely to occur in districts closer to the city center, so the introduction of paid parking is not random over space. To address this issue, we employ a difference-in-difference analysis between treated and non-treated areas by including zip-code fixed effects. Zip-code areas are small and contain, on average, only 15 houses. Furthermore, we only include areas where paid parking was introduced in the last 30 years. ${ }^{2}$ The introduction of paid parking in a neighborhood may increase or decrease the attractiveness of a location and may therefore affect house prices. The induced price change may not necessarily be instantaneous. Prices may change in anticipation of the parking policy change, or may adjust to the parking policy change after implementation. In both cases, one tends to underestimate the effect of the introduction of paid parking in our setup. To mitigate this issue, we exclude observations within one year before and after the introduction of paid parking.

Let $y_{i j t}$ the logarithm of the price of apartment $i$ in district $j$ in year $t$. We control for housing attributes $h_{i t}$, include year fixed effects $\theta_{t}$, and control for the possibility that prices

1 A positive effect of the parking policy implies severe cruising for parking prior to the introduction of paid parking, suggesting that paid parking was introduced too late from the residents' perspective. A negative policy effect implies the absence of substantial residential cruising, indicating that paid parking was introduced too early from the residents standpoint.

${ }^{2}$ Hence, we exclude areas where paid parking was never introduced and areas where paid parking was introduced before the period investigated. 
have developed differently within the city center than in the suburbs. This implies that we include a distance-year interaction effect, where $d_{i}$ refers to the distance to the city center and $\tau_{t}$ refers to year. Hence, the preferred specification to be estimated is:

$$
y_{i j t}=\alpha p_{j t}+\beta c_{i t}+\gamma\left(p_{j t} \times O_{i t}\right)+\delta h_{i t}+\eta_{i}+\theta_{t}+\left(d_{i} \times \tau_{t}\right)+\varepsilon_{i j t},
$$

where $p_{j t}$ is a dummy indicating whether district $j$ has paid parking at time $t, c_{i t}$ is a vector of private parking characteristics including privately-owned parking $O_{i t}, \eta_{i}$ are zip-code fixed effects, and $\varepsilon_{i j t}$ is an independently and identically distributed error term and. Hence, $\alpha$ measures the impact of a paid-parking policy, while $\gamma$ measures the price effects for private parking spaces. The introduction of paid parking may decrease the value of privately-owned parking because a cheap alternative (the costs of a permit) is available. To allow for this, we interact a paid-parking area dummy $p_{j t}$ with a privately-owned parking dummy $O_{i t}, \beta, \gamma, \eta_{i}$ and $\theta_{t}$ are other parameters to be estimated.

As apartments with private parking may have been constructed in different times and the price developments of apartments from different times may have been different, we also include a construction decade-year interaction effect.

\section{Data}

We use housing transaction data from 1985 to 2014 from the Dutch Brokers Association (NVM), which includes over 2.5 million observations of all across the Netherlands and provides us with detailed information about housing transactions. The dataset includes house prices and house characteristics, like surface area, construction year and location. We use the most detailed 6-digit zip code (roughly comparable to a US census block) to identify the location of the houses. In order to reduce heterogeneity between houses over time, we only use the 5-digit zip code areas that existed before the year 2000, so newly-built neighborhoods with possibly different supply of parking facilities are excluded. This leaves us with 123,260 observations for Amsterdam and Utrecht.

We have obtained information on parking districts from both municipalities and verified for each district the year of implementation. For Amsterdam we have 40 parking districts of which the average size is 139 hectares. For Utrecht we have 33 parking districts that are on average 27 hectares. Figure 1 shows the paid-parking districts including when paid parking was introduced. It can be clearly seen that paid parking was first introduced in the city center and later in areas around the center.

Table 1 reports the main descriptives for the full dataset, but also for the subsets of paidparking areas, no-paid-parking areas and the transition areas, where paid parking was introduced during the study period (1985-2014). The average house price is on average 


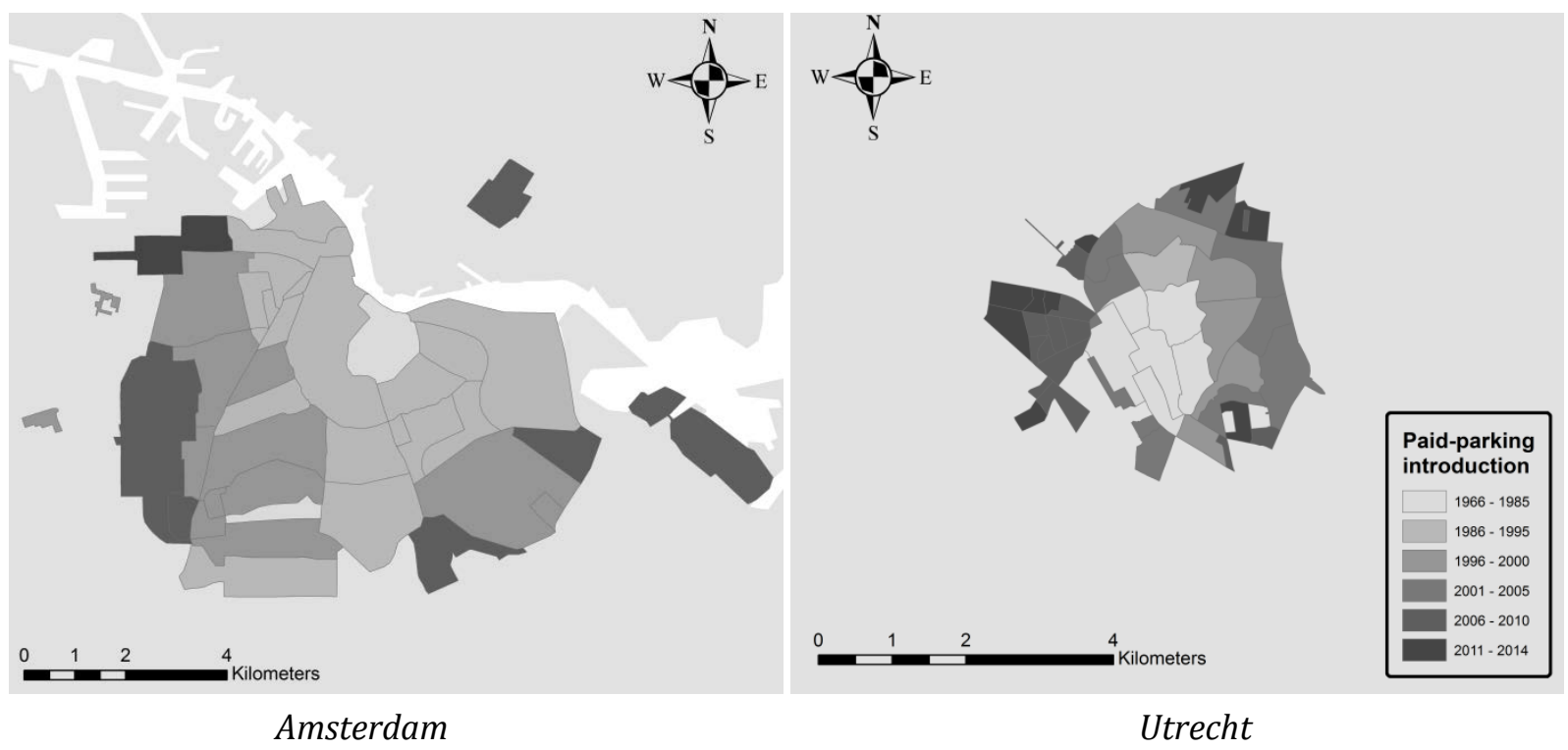

Figure 1: Paid-parking districts in Amsterdam and Utrecht.

Table 1: Descriptives: Amsterdam and Utrecht

\begin{tabular}{lcccc}
\hline & $\begin{array}{c}\text { Full } \\
\text { Dataset }\end{array}$ & $\begin{array}{c}\text { Paid } \\
\text { parking }\end{array}$ & $\begin{array}{c}\text { No paid } \\
\text { parking }\end{array}$ & $\begin{array}{c}\text { Implementation } \\
\text { areas }\end{array}$ \\
\hline House price $(€)$ & 213,555 & 253,095 & 131,908 & 232,885 \\
Floor space $\left(m^{2}\right)$ & 81.7 & 81.9 & 81.3 & 82.0 \\
Number of rooms & 3.07 & 3.02 & 3.16 & 3.07 \\
Constructed before 1945 & 0.589 & 0.723 & 0.313 & 0.731 \\
Outdoor parking & 0.021 & 0.016 & 0.032 & 0.017 \\
Garage parking & 0.048 & 0.047 & 0.052 & 0.042 \\
Year & 2004.6 & 2006.2 & 2001.2 & 2004.9 \\
Number of observations & 123,260 & 83,044 & 40,216 & 90,313 \\
\hline
\end{tabular}

$€ 214,000$. Houses are small in Amsterdam and Utrecht $\left(82 \mathrm{~m}^{2}\right.$ versus $117 \mathrm{~m}^{2}$ for all the Netherlands). In Table 1 we also observe that paid parking areas are usually close to the center, as the average house price is much higher than in areas without paid parking ( $€ 253,000$ versus $€ 132,000$ ). Areas where paid parking is implemented during the study period are comparable to the paid parking areas.

\section{Results}

As we have information on the location and timing of paid parking, we can estimate the direct effect of paid parking on house prices and on the value of privately-owned parking 
Table 2: House price: Amsterdam and Utrecht

(dependent variable: the log of house price)

\begin{tabular}{|c|c|c|c|c|}
\hline & (1) & (2) & (3) & (4) \\
\hline & Full Sample & $\begin{array}{c}\text { Implementation } \\
\text { areas }\end{array}$ & Amsterdam & Utrecht \\
\hline Paid parking & $0.039^{* * *}$ & -0.011 & 0.009 & 0.003 \\
\hline & $(0.013)$ & $(0.013)$ & $(0.019)$ & $(0.011)$ \\
\hline Paid parking $\times$ private parking & $0.026^{* *}$ & -0.016 & -0.026 & -0.004 \\
\hline & $(0.011)$ & $(0.016)$ & $(0.018)$ & $(0.018)$ \\
\hline Outdoor parking & $0.029^{* * *}$ & $0.064^{* * *}$ & $0.073^{* * *}$ & $0.086^{* * *}$ \\
\hline & $(0.008)$ & $(0.016)$ & $(0.019)$ & $(0.019)$ \\
\hline Garage parking & $0.060^{* * *}$ & $0.093^{* * *}$ & $0.103^{* * *}$ & $0.087^{* * *}$ \\
\hline & $(0.009)$ & $(0.017)$ & $(0.021)$ & $(0.021)$ \\
\hline Log size & $0.770^{* * *}$ & $0.774 * * *$ & $0.853^{* * *}$ & $0.839 * * *$ \\
\hline & $(0.041)$ & $(0.062)$ & $(0.021)$ & $(0.043)$ \\
\hline Log size $\times$ distance to city center & -0.005 & -0.004 & -0.024 & $-0.185^{* * *}$ \\
\hline & $(0.027)$ & $(0.045)$ & $(0.023)$ & $(0.044)$ \\
\hline Log size $\times$ distance to city center ${ }^{2}$ & -0.003 & 0.002 & 0.001 & -0.003 \\
\hline & $(0.003)$ & $(0.007)$ & $(0.004)$ & $(0.010)$ \\
\hline Garden & $-0.033^{* * *}$ & $-0.031^{* * *}$ & $-0.029^{* * *}$ & -0.014 \\
\hline & $(0.006)$ & $(0.006)$ & $(0.006)$ & $(0.018)$ \\
\hline Garden maintenance & $0.098^{* * *}$ & $0.102^{* * *}$ & $0.099 * * *$ & $0.113^{* * *}$ \\
\hline & $(0.006)$ & $(0.004)$ & $(0.005)$ & $(0.006)$ \\
\hline Central heating & $0.062^{* * *}$ & $0.064^{* * *}$ & $0.068^{* * *}$ & $0.050^{* * *}$ \\
\hline & $(0.006)$ & $(0.006)$ & $(0.007)$ & $(0.005)$ \\
\hline Insulation (5) & yes & yes & yes & yes \\
\hline Construction year (7) & yes & yes & yes & yes \\
\hline Construction year × year $(7 x 30)$ & yes & yes & yes & yes \\
\hline Distance to city center $\times$ year $(30)$ & yes & yes & yes & yes \\
\hline Zip-code fixed effects (8789) & yes & yes & yes & yes \\
\hline Year fixed effects (30) & yes & yes & yes & yes \\
\hline Number of observations & 123,260 & 90,313 & 78,938 & 11,375 \\
\hline $\mathrm{R}^{2}$ & 0.951 & 0.951 & 0.954 & 0.941 \\
\hline
\end{tabular}

Notes: In columns (2)-(4) we only include districts in which paid parking is introduced during the study period. Standard errors are in parentheses and clustered at the parking-district level. ${ }^{* * *}$ $\mathrm{p}<0.01,{ }^{* *} \mathrm{p}<0.5,{ }^{*} \mathrm{p}<0.10$.

spaces. We cluster the standard errors at the parking district level. The results are reported in Table 2.

Column (1) relies on the full dataset including apartments throughout the cities of Amsterdam and Utrecht. We find that the introduction of paid parking seems to have had a positive effect on house prices: prices are 3.9 percent higher in paid parking areas. Properties with garage parking space are 6 percent more expensive, while having an outdoor private parking space implies a price increase of 2.9 percent. We find that private parking spaces are almost 100 percent more expensive in paid parking areas, which 
probably reflects the fact that land has become more expensive in and close to city centers. In any case, this coefficient is unlikely to reflect a causal effect of parking policies.

To address the issue that paid parking areas may have had different temporal trends from free parking areas, we only include observations in parking districts in which paid parking is introduced after 1985. This reduces the number of observations by about 25 percent and implies that we identify the effect of parking policies based on differences in the timing of implementation. Column (2) suggests that the direct effect of paid parking on house prices disappears. Also, the indirect effect via a change in the price of private parking spaces is far from being statistically significant.

In columns (3) and (4) in Table 2 we make a distinction between Amsterdam and Utrecht respectively, as cities may have very different unobserved traits that may be correlated to changes in parking policies. However, it is confirmed that parking policies do not affect house prices in neither Amsterdam nor Utrecht. Given the 95-percent confidence interval the direct price effect in Amsterdam is maximally 4.6 percent $(0.009+1.96 \times 0.019)$, while the negative indirect effect on parking spaces is maximally 6.2 percent $(-0.026-1.96 \times$ $0.019)$. For Utrecht the maximum effects are even smaller, despite the fact that we only have a little more than 11,000 observations.

Hence, our results imply that the house price effects of paid parking policies are unlikely to be large. Given the absence of an effect, this suggests that any benefits of paid parking (e.g. less cruising) are offset by additional costs (e.g. permit costs, visitors that have to pay, not be able to park a second car). Hence, paid parking seems to be implemented at the moment residents are indifferent between paid and free parking.

\section{Sensitivity analysis}

We will now perform a battery of sensitivity analyses, which are reported in Table 3. In columns (1) to (3), we focus on Amsterdam and in the columns (4) to (6) we pay attention to Utrecht.

In column (1) we include not only apartments, but all other housing types (terraced, semi-detached and detached properties). This increases the number of observations somewhat (about 5 percent), but leaves the results unaffected. In column (2) we try to further aim to address the issue of unobserved trends that are correlated to the introduction of paid parking by including a squared interaction term of distance to the city center and transaction year. Again we do not find any effect. In column (3) we make a distinction between the effect of paid parking on the value of private outside and garage parking spaces. Both coefficients are statistically insignificant, but interestingly, the outdoor parking coefficient is positive, while the garage parking coefficient is negative. Hence, paid parking may have had some negative effects on the value of garage parking. But again, the standard 
Table 3: House price: Amsterdam and Utrecht: sensitivity analysis (dependent variable: the log of house price)

\begin{tabular}{|c|c|c|c|c|c|c|}
\hline & (1) & $(2)$ & (3) & (4) & (5) & (6) \\
\hline & \multicolumn{3}{|c|}{ Amsterdam } & \multicolumn{3}{|c|}{ Utrecht } \\
\hline Paid parking & $\begin{array}{c}0.010 \\
(0.017)\end{array}$ & $\begin{array}{c}0.019 \\
(0.022)\end{array}$ & $\begin{array}{c}0.009 \\
(0.019)\end{array}$ & $\begin{array}{c}-0.001 \\
(0.009)\end{array}$ & $\begin{array}{l}-0.001 \\
(0.012)\end{array}$ & $\begin{array}{l}-0.003 \\
(0.012)\end{array}$ \\
\hline Paid parking $\times$ private parking & $\begin{array}{l}-0.018 \\
(0.015)\end{array}$ & $\begin{array}{l}-0.014 \\
(0.020)\end{array}$ & & $\begin{array}{l}-0.016 \\
(0.012)\end{array}$ & $\begin{array}{l}-0.004 \\
(0.018)\end{array}$ & \\
\hline Paid parking $\times$ outdoor parking & & & $\begin{array}{c}-0.0002 \\
(0.011)\end{array}$ & & & $\begin{array}{c}0.024 \\
(0.019)\end{array}$ \\
\hline Paid parking $\times$ garage parking & & & $\begin{array}{l}-0.051 \\
(0.029)\end{array}$ & & & $\begin{array}{l}-0.027 \\
(0.033)\end{array}$ \\
\hline Outdoor parking & $\begin{array}{c}0.067^{* * *} \\
(0.017)\end{array}$ & $\begin{array}{c}0.062^{* * *} \\
(0.021)\end{array}$ & $\begin{array}{c}0.053^{* * *} \\
(0.012)\end{array}$ & $\begin{array}{c}0.055^{* * *} \\
(0.021)\end{array}$ & $\begin{array}{c}0.085^{* * *} \\
(0.019)\end{array}$ & $\begin{array}{c}0.064^{* * *} \\
(0.023)\end{array}$ \\
\hline Garage parking & $\begin{array}{c}0.093^{* * *} \\
(0.017)\end{array}$ & $\begin{array}{c}0.091^{* * *} \\
(0.022)\end{array}$ & $\begin{array}{c}0.126^{* * * *} \\
(0.029)\end{array}$ & $\begin{array}{c}0.060^{* * *} \\
(0.013)\end{array}$ & $\begin{array}{c}0.086^{* * *} \\
(0.021)\end{array}$ & $\begin{array}{c}0.104^{* * *} \\
(0.024)\end{array}$ \\
\hline Insulation (5) & yes & yes & yes & yes & yes & yes \\
\hline Construction year (7) & yes & yes & yes & yes & yes & yes \\
\hline Construction year × year (7x30) & yes & yes & yes & yes & yes & yes \\
\hline Distance to city center $\times$ year $(30)$ & yes & yes & yes & yes & yes & yes \\
\hline Distance to city center ${ }^{2} \times$ year $(30)$ & no & yes & no & no & yes & no \\
\hline Zip-code fixed effects (6619) & yes & yes & yes & yes & yes & yes \\
\hline Year fixed effects (30) & yes & yes & yes & yes & yes & yes \\
\hline Number of observations & 82,789 & 78,938 & 78,938 & 23,908 & 11,375 & 11,375 \\
\hline $\mathrm{R}^{2}$ & 0.953 & 0.954 & 0.954 & 0.949 & 0.941 & 0.941 \\
\hline
\end{tabular}

Notes: We only include districts in which paid parking is introduced during the study period. Standard errors are in parentheses and clustered at the parking-district level. ${ }^{* * *} \mathrm{p}<0.01,{ }^{* *} \mathrm{p}<0.5,{ }^{*}$ $\mathrm{p}<0.10$.

errors are too large to make precise statements. We repeat the same set of specifications for Utrecht in columns (4)-(6), confirming the absence of a statistically significant effect on paid parking.

Throughout the analysis we assume that the value of parking space relative to the house has remained constant over time. We have tested if the value of private parking has changed over time in the Netherlands. Figure A1 in the Appendix shows that the garage coefficient has remained roughly constant over time and that there is no difference between cities with and without paid parking. For a more detailed discussion on the relative value of parking space over time we refer to the Appendix.

\section{Conclusion}

In our analysis we have estimated changes in house prices as a result of changes in parking policy - i.e. the introduction of paid parking and introduction of residential parking permits in two large Dutch cities for a period of about 30 years. The most important result from the analysis is that there is no statistically significant effects of parking policy on house prices. 
We neither find a direct effect, nor an effect via the willingness to pay for a private parking space. This strongly suggests that paid parking has been introduced at about the moment where residents are indifferent between paid and free parking.

The influence of the introduction of paid parking on house prices of residence is with private parking space is less clear, but most likely there is no effect. Some findings suggest that the economic value of privately-owned parking is reduced when paid parking is introduced.

Can we say anything about the welfare effects of the introduction of paid parking? The absence of any negative effect on local residents strongly signal a positive welfare effect of this policy, as the introduction of paid parking for nonresidents likely has improved the efficiency of this market. However, for a more elaborate welfare analysis, one should also consider the welfare effects on visitors and commercial activities such as retail. We leave this for further research.

\section{References}

Anderson, S. P., and de Palma, A. (2004). The economics of pricing parking. Journal of Urban Economics, 55(1), 1-20.

Arnott, R. (2006). Spatial competition between parking garages and downtown parking policy. Transport Policy, 13(6), 458-469.

Arnott, R., de Palma, A., and Lindsey, R. (1991). A temporal and spatial equilibrium analysis of commuter parking. Journal of Public Economics, 45(3), 301-335.

Arnott, R., and Inci, E. (2006). An integrated model of downtown parking and traffic congestion. Journal of Urban Economics, 60(3), 418-442.

Arnott, R., and Rowse, J. (1999). Modeling Parking. Journal of Urban Economics, 124, 97-124.

Arnott, R., and Rowse, J. (2009). Downtown parking in auto city. Regional Science and Urban Economics, 39(1), 1-14.

Brown, J. N., and Rosen, H. S. (1982). On the estimation of structural hedonic price models. Econometrica, 50(3), 765-768.

Button, K. (2006). The political economy of parking charges in "first" and "second-best" worlds. Transport Policy, 13(6), 470-478.

Dargay, J., and Gately, D. (1999). Income's effect on car and vehicle ownership, worldwide: 19602015. Transportation Research Part A: Policy and Practice.

De Borger, B., and Proost, S. (2012). A political economy model of road pricing. Journal of Urban Economics, 71(1), 79-92.

Kodransky and Hermann, G., M. (2011). Europe's parking U-turn: From accommodation to regulation. Institute for Transportation and Development Policy, 84.

Marcucci, E., Marini, M., and Ticchi, D. (2005). Road pricing as a citizen-candidate game. European Transport, 31, 28-45.

Palmquist, R. B. (1984). Estimating the Demand for the Characteristics of Housing. The Review of Economics and Statistics, 66(3), 394-404.

Rosen, S. (1974). Hedonic Prices and Implicit Markets: Product Differentiation in Pure Competition. Journal of Political Economy, 82(1), 34-55.

Russo, A. (2013). Voting on road congestion policy. Regional Science and Urban Economics, 43(5), 707-724.

Shoup, D. C. (2004). The ideal source of local public revenue. Regional Science and Urban Economics, 34(6), 753-784.

Topp, H. H. (1991). Parking policies in large cities in Germany. Transportation, 18(1), 3-21. 
Van Ommeren, J. N., Wentink, D., and Rietveld, P. (2012). Empirical evidence on cruising for parking. Transportation Research Part A: Policy and Practice, 46(1), 123-130.

Van Ommeren, J., Wentink, D., and Dekkers, J. (2011). The real price of parking policy. Journal of Urban Economics, 70(1), 25-31.

Verkeersnet. (2013). Utrecht schrapt draagvlakmetingen bij invoering betaald parkeren. Retrieved from http://www.verkeersnet.nl/9325/utrecht-schrapt-draagvlakmetingen-bijinvoering-betaald-parkeren/

Whelan, G. (2007). Modelling car ownership in Great Britain. Transportation Research Part A: Policy and Practice, 41(3), 205-219.

\section{Appendix. Private parking space in the Netherlands}

It may be insightful to see if paid parking is associated with the relative value of private parking spaces. Based on reported parking revenues, we can distinguish between municipalities with and without paid parking. In 2009, about 36 percent of the Dutch municipalities had paid parking. As paid parking is more common in the larger municipalities, 64 percent of the observations, or about 1.5 million observations, is within a city with paid parking. We can derive whether or not the relative value of private parking space has increased (for example, due to increased car ownership) or decreased over time and whether this development has been different between municipalities with and without paid parking. The analysis suggests that garage parking space is rather consistently more valuable in municipalities without paid parking, but that the difference is only about one percent of the total house price.

The main analysis assumes that the relative value of parking space has remained constant over time. The relative value of parking space may, however, have changed over time unrelated to parking policy. Therefore we have also estimated a model using data on the whole of the Netherlands. We distinguish between cities with and without paid parking, so we can compare the development of the relative value of parking space between cities with and without paid parking. We have estimated this model separately for every year, so we can track the coefficients related to private parking spaces over time. In short, the model looks as follows:

$$
y_{i j t}=\beta_{t} c_{i t}+\gamma_{t} h_{i t}+\eta_{i t}+\varepsilon_{i j t}
$$

for every year in the dataset. As we estimate the coefficients per year, we do not need year dummies or year interaction effects. As we estimate the zip-code fixed effects $\eta_{i t}$ per year, we also control for very local differences in house-price developments.

We report the descriptive stats for the full sample in Table A1. Average house prices have increased from $€ 64,000$ in 1985 to nearly $€ 200,000$ in 2008 . In the dataset 10 percent of the apartments possesses a private garage parking spot and another 6 percent possessed an outdoor parking spot. Apartments with garage parking were generally larger and more 
Table A1: Descriptives: the Netherlands

\begin{tabular}{lcccc}
\hline & Full dataset & Apartments & $\begin{array}{c}\text { Apartments with } \\
\text { garage parking }\end{array}$ & $\begin{array}{c}\text { Apartments with } \\
\text { Outdoor parking }\end{array}$ \\
\hline House price $(€)$ & 194,881 & 162,330 & 232,596 & 191.342 \\
Floor space $\left(\mathrm{m}^{2}\right)$ & 117.3 & 86.0 & 105.1 & 92.7 \\
Number of rooms & 4.35 & 3.22 & 3.24 & 3.05 \\
Apartment & 0.27 & 1.00 & 1.00 & 1.00 \\
Constructed before 1945 & 0.26 & 0.28 & 0.05 & 0.05 \\
Year & 2003.2 & 2004.4 & 2004.8 & 2005.1 \\
Number of observations & $2,409,379$ & 653,455 & 66,758 & 40,995 \\
\hline
\end{tabular}

Table A2: Value of a privately-owned parking spot

(dependent variable: the log of house price)

\begin{tabular}{lccccc}
\hline & $1990-1994$ & $1995-1999$ & $2000-2004$ & $2005-2009$ & $2010-2014$ \\
\hline Outdoor parking & 0.005 & $0.029^{* * *}$ & $0.053^{* * *}$ & $0.045^{* * *}$ & $0.048^{* * *}$ \\
(paid parking) & $(0.008)$ & $(0.004)$ & $(0.002)$ & $(0.002)$ & $(0.003)$ \\
Outdoor parking & 0.022 & $0.047^{* * *}$ & $0.047^{* * *}$ & $0.028^{* * *}$ & $0.041^{* * *}$ \\
(no paid parking) & $(0.015)$ & $(0.009)$ & $(0.005)$ & $(0.004)$ & $(0.004)$ \\
Garage parking & $0.088^{* * *}$ & $0.120^{* * *}$ & $0.097^{* * *}$ & $0.084^{* * *}$ & $0.079^{* * *}$ \\
(paid parking) & $(0.007)$ & $(0.004)$ & $(0.002)$ & $(0.002)$ & $(0.002)$ \\
Garage parking & $0.091^{* * *}$ & $0.109^{* * *}$ & $0.114^{* * *}$ & $0.083^{* * *}$ & $0.091^{* * *}$ \\
(no paid parking) & $(0.011)$ & $(0.008)$ & $(0.005)$ & $(0.003)$ & $(0.004)$ \\
\hline Floor space (log) & $0.667^{* * *}$ & $0.577^{* * *}$ & $0.611^{* * *}$ & $0.647^{* * *}$ & $0.701^{* * *}$ \\
& $(0.007)$ & $(0.004)$ & $(0.002)$ & $(0.002)$ & $(0.002)$ \\
Garden & 0.020 & -0.009 & $-0.016^{* *}$ & $-0.035^{* * *}$ & $-0.036^{* * *}$ \\
& $(0.026)$ & $(0.014)$ & $(0.006)$ & $(0.004)$ & $0.005)$ \\
Garden maintenance & $0.079^{* * *}$ & $0.079^{* * *}$ & $0.095^{* * *}$ & $0.092^{* * *}$ & $0.126^{* * *}$ \\
& $(0.004)$ & $(0.002)$ & $(0.001)$ & $(0.001)$ & $(0.001)$ \\
Central heating & $0.050^{* * *}$ & $0.073^{* * *}$ & $0.062^{* * *}$ & $0.045^{* * *}$ & $0.042^{* * *}$ \\
& $(0.005)$ & $(0.002)$ & $(0.001)$ & $(0.001)$ & $(0.002)$ \\
\hline Insulation (5) & yes & yes & yes & yes & yes \\
Construction year (7) & yes & yes & yes & yes & yes \\
Zip-codexyear fixed effects (8789) & yes & yes & yes & yes & yes \\
\hline Number of observations & 24,295 & 105,575 & 176,667 & 194,774 & 142,754 \\
$\mathrm{R}^{2}$ & 0.914 & 0.844 & 0.899 & 0.922 & 0.919 \\
\hline
\end{tabular}

Notes: Standard errors are in parentheses and clustered at the parking-district level. The asterisks indicate the $10\left(^{*}\right), 5\left(^{* *}\right)$ and $1 \%\left(^{* * *}\right)$ significance levels. All specifications include year and zip-code fixed effects and year-distance to city center interaction effects. Apartments constructed before 1945 are the reference categories.

expensive. Interestingly, apartments with a garage are generally more expensive than apartments without. This may indicate that garages have a non-negligible influence on house prices, but it may also be due to other characteristics, such as floor space, that are correlated with owning a garage. 


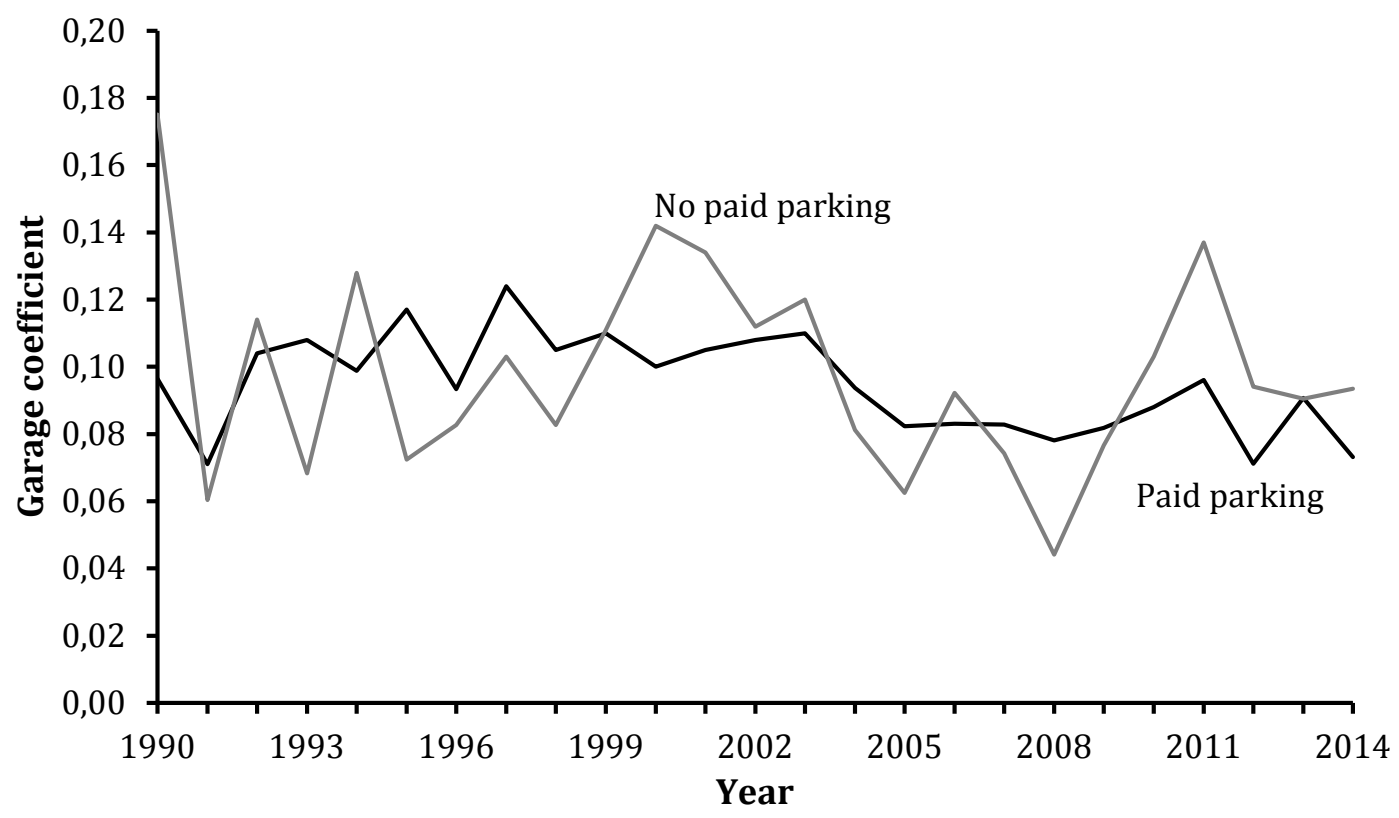

Figure A1: Relative value of garage parking space

We estimate the annual private-parking coefficients municipalities with and without paid parking. Table A2 shows the coefficients of the control variables at 5-year intervals. The coefficients of the control variables do change a bit over time, which suggests that apartment characteristics are valued differently over different time periods. Interestingly, the coefficient of floor space has changed considerably over time. The coefficient was relatively low in the mid-90s, but higher in the late 2000s. As expected, garage parking is valued higher than outdoor parking. On average, garage parking space increases the value of a house by about 10 percent (see also Figure A1, which shows the per-year garage coefficient) while outdoor parking space increase house prices with 4 percent. Interestingly, the relative value does not differ much between cities with and without paid parking. The year-to-year changes are substantial, but the patterns are very similar. The relative value of garage parking space peaked at around 2000, and has decreased afterwards. Hence, the absence of an effect of parking policies on house prices is unlikely to be explained by timevarying preferences for private parking spaces. 